\title{
Efficiency of instant messaging applications in coordination of emergency calls for combat injuries: A pilot study
}

\author{
Sami Eksert, M.D., ${ }^{1}$ Mehmet Burak Aşık, M.D., ${ }^{2}$ Sinan Akay, M.D., ${ }^{3}$ Kenan Keklikçi, M.D., ${ }^{4}$ \\ Fevzi Nuri Aydın, M.D., ${ }^{5}$ Mehmet Çoban, M.D., ${ }^{6}$ Ali Kantemir, M.D., ${ }^{4}$ Onur Güngör, M.D., ${ }^{7}$ \\ Beyazıt Garip, M.D., ${ }^{8}$ Mustafa Suphi Turgut, M.D., ${ }^{9}$ Kenan Olcay, M.D. ${ }^{10}$
}

\author{
${ }^{1}$ Department of Anesthesiology and Reanimation, Şırnak Military Hospital, Şırnak-Turkey \\ ${ }^{2}$ Department of Otolaryngology, Head and Neck Surgery, Şırnak Military Hospital, Şırnak-Turkey \\ ${ }^{3}$ Department of Radiology, Şırnak Military Hospital, Şırnak-Turkey \\ ${ }^{4}$ Department of Orthopedics and Traumatology, Şırnak Military Hospital, Şırnak-Turkey \\ ${ }^{5}$ Department of Biochemistry, Şırnak Military Hospital, Şırnak-Turkey \\ ${ }^{6}$ Department of Infectious Diseases, Şırnak Military Hospital, Şırnak-Turkey \\ ${ }^{7}$ Department of Pediatrics, Şırnak Military Hospital, Şırnak-Turkey \\ ${ }^{8}$ Department of Psychiatry, Şırnak Military Hospital, Şırnak-Turkey \\ ${ }^{9}$ Department of General Surgery, Şırnak Military Hospital, Şırnak-Turkey \\ ${ }^{10}$ Department of Eye Diseases, Şırnak Military Hospital, Şırnak-Turkey
}

\begin{abstract}
BACKGROUND: Coordination of an emergency response team is an important determinant of prompt treatment for combat injuries in hospitals. The authors hypothesized that instant messaging applications for smartphones could be appropriate tools for notifying emergency response team members. The objective of this study was to investigate the efficiency of a commercial instant messaging application (WhatsApp, Mountain View, CA) as a communication tool for the emergency team in a level-I trauma center.
\end{abstract}

METHODS: We retrospectively evaluated the messages in the instant messaging application group that was formed to coordinate responses to patients who suffered from combat injuries and who were transported to our hospital via helicopter during an 8-week period. We evaluated the response times, response time periods during or outside of work hours, and the differences in the response times of doctors, nurses, and technicians among the members of the emergency team to the team leader's initial message about the patients.

RESULTS: A total of 510 emergency call messages pertaining to 17 combat injury emergency cases were logged. The median time of emergency response was 4.1 minutes, 6 minutes, and 5.3 minutes for doctors, nurses, and the other team members, respectively. The differences in these response times between the groups were statistically significant $(p=0.03)$, with subgroup analyses revealing significant differences between doctors and nurses $(p=0.038)$. However, no statistically significant differences were observed between the doctors and the technicians $(p=0.19)$ or the nurses and the technicians $(p=1.0)$. From the team leader's perspective, using this application reduced the workload and the time loss, and also encouraged the team.

CONCLUSION: Instant messaging applications for smartphones can be efficient, easy-to-operate, and time-saving communication tools in the transfer of medical information and the coordination of emergency response team members in hospitals.

Keywords: Combat-related injuries; medical informatics; trauma.

Address for correspondence: Mehmet Burak Aşı, M.D. Şırnak Asker Hastanesi, 73000 Şırnak, Turkey Tel: +90 486 - 2181000 E-mail: burock312@yahoo.com

Ulus Travma Acil Cerrahi Derg

20I7;23(3):207-2।I

doi: $10.5505 /$ tjtes.2016.37897

Copyright 2017

TJTES

\section{INTRODUCTION}

Nowadays, smartphones represent an important part of modern life. As long as a signal is available, these devices ensure that we can communicate from nearly everywhere, access the Internet, check e-mails, and follow social networks. In Turkey alone, $58 \%$ of the population uses cell phones and smartphones to access the internet outside their homes and workplaces. ${ }^{[1]}$

In the surgical and emergency fields, members of any division 
generally communicate verbally via telephones. Such communication can be rapid if it occurs between two people. However, if more than one member of the team needs to be informed, the telephone may not be the fastest and most appropriate tool for communication. Furthermore, such communication can, at times, lack objectivity and precision. ${ }^{[2]}$ Nowadays, with technological advancements occurring at an unprecedented pace, images taken by a smartphone can be instantly transferred to another smartphone via specific applications, ${ }^{[3-5]}$ and this technique is used as a communication method among physicians during patient evaluations.

Founded in 2009 by Brian Acton and Jan Koum, WhatsApp (Mountain View, CA, USA) is an instant messaging application for smartphones. It is a proprietary application and operates under a subscription business model used for sending messages, images/photos, videos, audio media messages, and the user's location. WhatsApp is the most popular messaging application globally, with the number of its active users reaching 900 million in September 2015. ${ }^{[6]}$

Limited studies ${ }^{[2,7]}$ have investigated the role and efficiency of using social media services in medical practices. The present study hypothesizes that instant messaging applications are effective and fast communication tools for an emergency team (ET) in combat injuries. The study aims to investigate the efficiency of this smartphone application as a communications tool for the ET at a level-I trauma center.

\section{MATERIALS AND METHODS}

The present study was conducted at a level-I trauma hospital, which is the primary center for combat injuries in its region. The study protocols were approved by Kecioren Research and Training Hospital institutional review board. In the past, ET members communicated using telephone calls during emergency cases in the hospital. Each ET comprises four distinct task teams: the transportation team, the triage-cardiopulmonary resuscitation team, the operation room and intensive care unit team, and the blood transfusion-laboratory team. An anesthesiologist, the ET leader, communicates the emergency calls to all team members and coordinates their actions. The emergency call process, the teams' tasks, and their respective actions are shown in a flowchart in Figure I.

An instant messaging application (WhatsApp, Mountain View, CA) message group was created for communicating emergency calls for combat injuries incurred on the tactical field to the team leader, facilitate the patient's transport to the trauma hospital, and coordinate all team members' actions. All ET members, already active users of the application, were included in this group. Communication and message rules were determined and texted to all team members via instant messaging application messages. Further messages were not sent to the team members to avoid Pygmalion and Hawthorne biases. These rules are shown in Figure 2.

After affirming an emergency case, the team leader texted

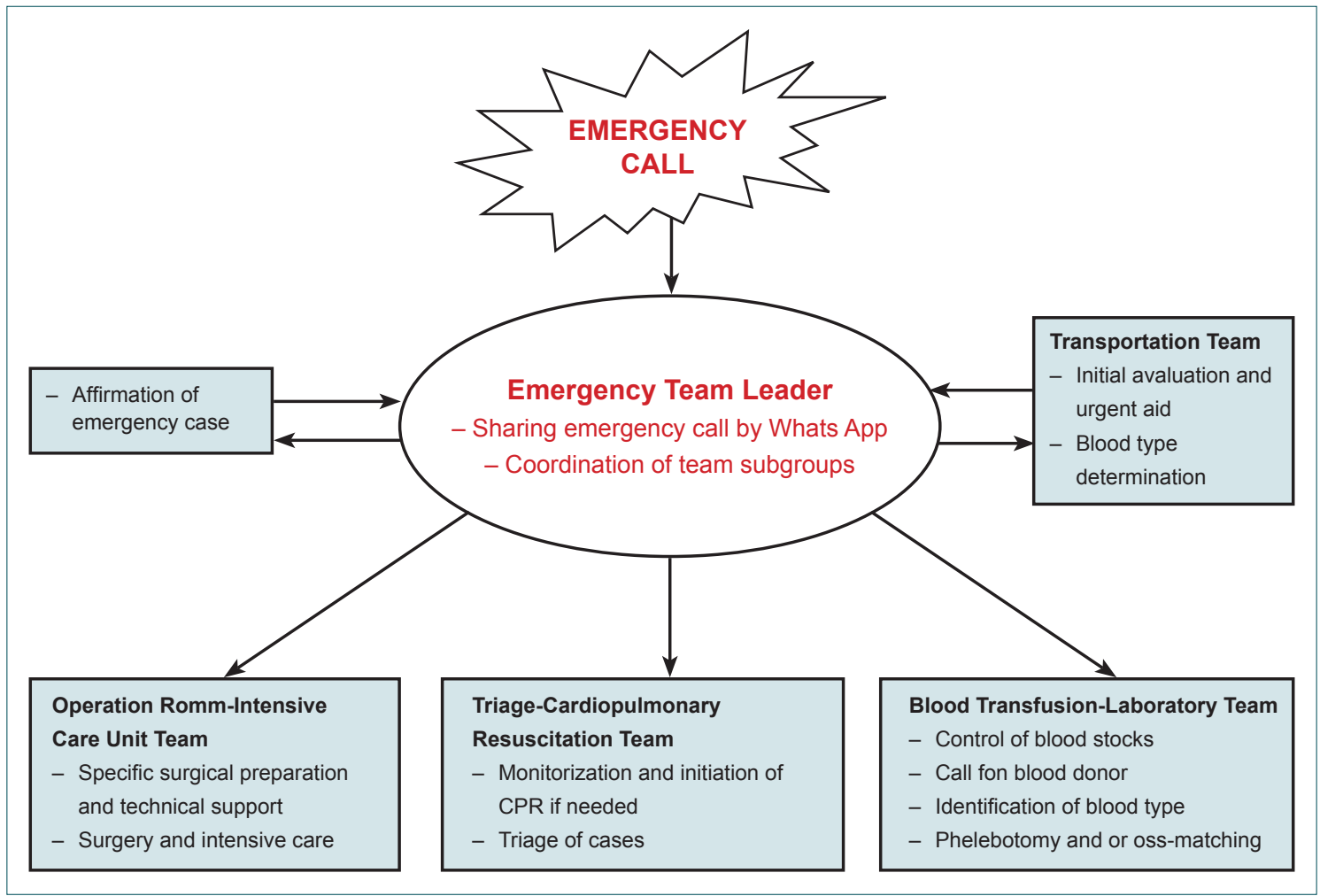

Figure 1. Emergency call flowchart. 
1. First emergency call was always made by the team leader.

2. It was forbidden to text social sharings.

3. It was forbidden to share patient's identity and nonethical pictures.

4. Whatsapp application and call signal should be got online 7 days/24 hours.

5. Respond to the emergency call within the shortest time as soon as possible.

Figure 2. Emergency communication rules.

and shared emergency call and patient information (Figure 3). A strict message format specific for each case was not used. However, origin time and the injury pattern, the affected organ or body region, the geographical location of the event, the patient's blood group (if applicable), transportation type, and the patient's expected arrival were the main components of the patient's information message.

A helicopter transported all cases from the tactical field. The team comprised I team leader, 13 doctors, 8 nurses, and 9 medical technicians, for a total of 31 members.

The instant messaging application was used as the official communication platform for two months, and a hard copy of the communications was printed out, stored, and checked by the team leader at regular intervals. We assessed the response time to emergency calls, response time periods inside or outside of working hours (00:00-08:00, 08:00-17:00, 17:00-24:00), and the differences in the response times of doctors, nurses, and technicians.

\section{Statistical Analyses}

Statistical analyses were performed using the SPSS software version I5 (Chicago, Illinois, USA). To determine whether the variables were normally distributed, they were investigated using visual (histograms, probability plots) and analytical methods (Shapiro-Wilk test). The descriptive analyses presented the means and standard deviations for the normally distributed "Responding Time" variable. To compare these parameters among the team member groups, one-way analysis of variance (ANOVA) was used. Levene's test was used to assess the homogeneity of the variances. When overall significance was observed, pairwise post-hoc tests were performed using the Bonferroni test. An overall pvalue of less than 0.05 was considered to be a statistically significant result.

\section{RESULTS}

A total of 510 emergency call messages pertaining to 17 combat injury emergency cases were logged. Of these, 221 were from doctors, 136 from nurses, and 153 from technicians. The messages were grouped according to response time, response time in different time periods, and the type of ET member (i.e., doctor, nurse, or technician).
田

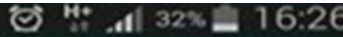
$\leftarrow \rightarrow$ Hastane acil durum gur..

2 yaralı gelecek

Biri ağır boyundan biri bacakta yaralı ?

Ok 21:5

Hava Sahası kapalı henüz helikopter kalkamadi 21.52 $x$

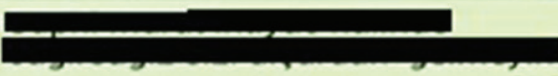

Helikopter kalkınca haber vereceğim 21:54 $\checkmark$
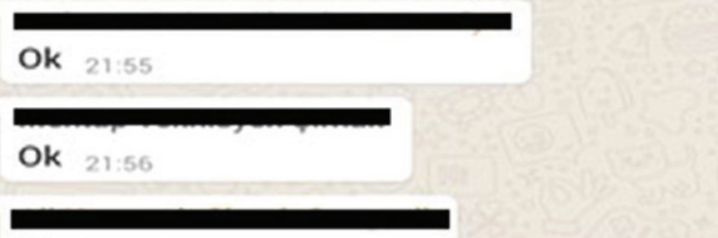

OK 21:57

(2) Bir mesaj yaz ㅇ.

Figure 3. Sample of instant messaging application message.

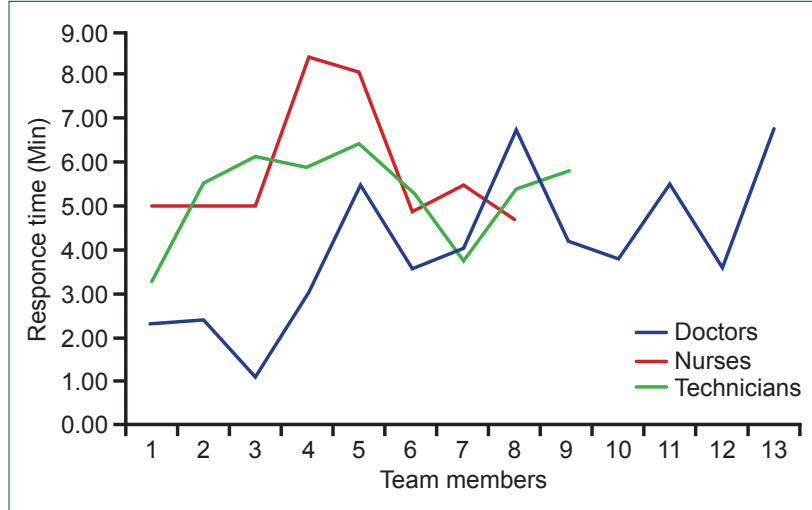

Figure 4. Individual response time graph.

\section{Response Time of Team Members}

Doctors responded to emergency calls in a median time of 4.I minutes, nurses in 6 minutes, and the other team members in 5.3 minutes. Between the groups, the differences in these response times were statistically significant $(p=0.03)$, with subgroup analyses revealing significant differences between the doctors and the nurses $(p=0.038)$. However, no statistically significant differences were observed between the doctors and the technicians $(p=0.19)$ or the nurses and the technicians $(p=1.0)$ (Figure 4).

\section{Response Times in Different Periods}

ET members responded to emergency calls during normal 
working hours, 08:00-17:00, in a median time of 4.5 minutes, between 17:00-24:00, in a median time of 4.5 minutes, and between 00:00-08:00 in a median time of 6.0 minutes. Of the emergency calls, 12 out of 17 occurred during the normal working hours of 08:00-17:00.

\section{DISCUSSION}

According to the results of and experiences in the present study, we can conclude that an instant messaging application is efficient for ET coordination in combat injuries, although it was not compared with other communication tools. However, a single source relayed the exact information to the emergency team within a short time, and the anecdotal data from the team leader's perspective shows that the team leader's energy and time loss were reduced by using the instant messaging application.

Used by more than 900 million people worldwide, WhatsApp is a commonly used and popular smartphone application [6]. It enables the sharing of text messages, videos, voice messages, and photographs. It also allows for simultaneous communication with multiple online consumers. Moreover, it is widely used by healthcare professionals for social messaging. The authors of the present study concluded that an instant messaging application is a useful communication tool for the transfer of medical information among healthcare professionals because of its widespread use and fast and efficient features.

Few studies in the existing medical literature examine the use of instant messaging applications for smartphones in the medical field. Johnston et al. ${ }^{[7]}$ reported that WhatsApp is a safe and efficient application for communication within emergency surgical teams. Wani et al. ${ }^{[2]}$ demonstrated that WhatsApp is a cheap, fast, and easy-to-operate tool for communication between plastic and reconstructive surgeons. The current study also indicated that it is an efficient and timesaving tool for communicating with the ET. Response times were compared in the present study, similar to the study by Johnston et al.; ${ }^{[7]}$ the response times of the doctors were found to be significantly shorter than those of the other two groups. The reason for this difference may be the more efficient role played by doctors in the ET.

In contrast to the existing literature on this subject, the response times were also assessed in three different time periods (00:00-08:00, 08:00-17:00, and 17:00-24:00) in the current study; no statistically significant differences were observed. Because this is a pilot study, further studies examining more number of cases are essential.

This study has some limitations. Differences in the signal coverage of the Global System for Mobile (GSM) operators used by the various team members and occasional internet restrictions in the region where the hospital is located might have affected the attainability and timeliness of the responses. Easy access to patient information and verbal communication by the team members within the hospital facilities might have influenced their less frequent use of the text messaging system. Finally, the limited number of emergency events and the lack of a comparative study with another communication tool, such as a pager or a telephone, were the other limitations of the present study.

\section{Conclusion}

Although WhatsApp is an efficient and commonly used smartphone application, its medical use is limited. Only a few studies in existing medical literature have explored this subject. In the current study, based on the experiences of ET members, the authors concluded that WhatsApp is an efficient, easy-tooperate, and time-saving communication tool for the transfer of medical information and the coordination of ET members. Furthermore, the response times of the doctors were significantly shorter than those of the other ET members.

\section{Key Messages}

- Coordination among emergency response team members is an important determinant for the prompt treatment of combat injuries.

- WhatsApp (Mountain View, CA, USA) is an instant messaging application for smartphones and operates under a subscription business model used for sending messages, images/photos, videos, and audio media messages.

- Although instant messaging applications for smartphones are efficient and commonly used, their use in the medical field is limited.

- WhatsApp is an efficient, easy-to-operate, and time-saving communication tool for the transfer of medical information and the coordination of ET members, according to their experiences.

- The role and efficiency of using social media services in medical practices requires further study.

\section{Sponsor}

None

\section{Funding Source}

None

\section{Ethical Approval}

This article does not contain any studies with human participants or animals performed by any of the authors.

Conflict of interest: None declared.

\section{REFERENCES}

1. Turkish Statistics Institute. News Bulletin 2014.

2. Wani SA, Rabah SM, Alfadil S, Dewanjee N, Najmi Y. Efficacy of com- 
munication amongst staff members at plastic and reconstructive surgery section using smartphone and mobile WhatsApp. Indian J Plast Surg 2013;46:502,5.

3. Baldwin AJ, Langton SG. Postoperative monitoring of flaps by digital camera and Internet link. Br J Oral Maxillofac Surg 2001;39:120-1. [CrossRef]

4. Varkey P, Tan NC, Girotto R, Tang WR, Liu YT, Chen HC. A picture speaks a thousand words: the use of digital photography and the Internet as a cost-effective tool in monitoring free flaps. Ann Plast Surg 2008;60:45-8. [CrossRef]
5. Engel H, Huang JJ, Tsao CK, Lin CY, Chou PY, Brey EM, et al. Remote real-time monitoring of free flaps via smartphone photography and $3 \mathrm{G}$ wireless Internet: a prospective study evidencing diagnostic accuracy. Microsurgery 2011;31:589-95. [CrossRef]

6. Wikipedia, the free encyclopedia en [Last updated on Sep 5, 2015]. Available from https://en.wikipedia.org/wiki/WhatsApp.

7. Johnston MJ, King D, Arora S, Behar N, Athanasiou T, Sevdalis N, et al. Smartphones let surgeons know WhatsApp: an analysis of communication in emergency surgical teams. Am J Surg 2015;209:45-51. [CrossRef]

\section{ORIJINAL ÇALIŞMA - ÖZET}

\section{Anlık mesajlaşma uygulamasının harp kaynaklı yaralanmalar için acil iletişim koordinasyonunda kullanım verimliliği: Pilot çalışma \\ Dr. Sami Eksert, ${ }^{1}$ Dr. Mehmet Burak Aşık, ${ }^{2}$ Dr. Sinan Akay, ${ }^{3}$ Dr. Kenan Keklikçi, ${ }^{4}$ Dr. Fevzi Nuri Aydın, ${ }^{5}$ Dr. Mehmet Çoban, ${ }^{6}$ Dr. Ali Kantemir, ${ }^{4}$ Dr. Onur Güngör, ${ }^{7}$ Dr. Beyazıt Garip, ${ }^{8}$ Dr. Mustafa Suphi Turgut, ${ }^{9}$ Dr. Kenan Olcay ${ }^{10}$}

'Şırnak Asker Hastanesi, Anestezi ve Reanimasyon Kliniği, Şırnak

${ }^{2}$ Şırnak Asker Hastanesi Kulak Burun Boğaz ve Baş-Boyun Cerrahisi Kliniği, Şırnak

${ }^{3}$ Şırnak Asker Hastanesi Radyoloji Kliniği, Şırnak

${ }^{4}$ Şırnak Asker Hastanesi Ortopedi ve Travmatoloji Kliniği, Şırnak

5Şırnak Asker Hastanesi, Biyokimya Kliniği, Şırnak

${ }^{6}$ Şırnak Asker Hastanesi, Enfeksiyon Hastalıkları Kliniği, Şırnak

${ }^{7}$ Şırnak Asker Hastanesi, Çocuk Hastalıkları Kliniği, Şırnak

${ }^{8}$ Şırnak Asker Hastanesi, Psikiyatri Kliniği, Şırnak

'Şırnak Asker Hastanesi, Genel Cerrahi Kliniği, Şırnak

${ }^{10}$ Şırnak Asker Hastanesi, Göz Hastalıkları Kliniği, Şırnak

AMAÇ: Acil müdahale ekibi koordinasyonu hastanelerde savaşa bağlı ateşli silah yaralanmalarında hızı ve etkin tedavinin önemli bir belirleyicisidir. Yazarlar akıllı telefonlar için anlık mesajlaşma uygulamalarının, acil müdahale ekip üyelerinin iletişimi için etkin bir araç olarak kullanılabileceğini düşünmektedir. Bu çalışmada, seviye I travma merkezinde acil ekibi iletişim aracı olarak ticari bir anlık mesajlaşma uygulamasının (WhatsApp, Mountain View, CA) etkinliği araştıldı.

GEREÇ VE YÖNTEM: Sekiz haftalık süre içinde helikopter ile hastanemize sevk edilen savaşa bağlı ateşli silah yaralanmaları ile ilgili anlık mesajlaşma uygulaması mesaj grubu kuruldu ve bu gruba ait mesajlar değerlendirildi. Acil ekip lideri tarafından yaralı ile ilgili gönderilen ilk bilgi mesajına acil ekip üyesi olan doktorlar, hemşireler ve teknisyenler tarafından verilen ortalama yanıt süreleri ve mesai içi veya mesai dışında ortalama yanıt süreleri değerlendirildi.

BULGULAR: On yedi çatışmaya bağlı ateşli silah yaralanması olgusuna ile ilgili 510 acil çağıı mesajı bulunmaktadır. Ekip üyesi doktor, hemşire ve teknisyenler tarafından ilk bilgi mesajına verilen ortalama yanıt süreleri sırasıyla 4. I dakika, 6 dakika ve 5.3 dakika idi. Gruplar arasında yanıt süreleri farkı $(p=0.03)$ istatistiksel olarak anlamlı idi. Alt grup analizinde ise doktorlar ve hemşireler $(p=0.038)$ arasında istatistiksel olarak anlamlı fark mevcuttu. Ancak, doktorlar ve teknisyenler $(p=0.19)$, ya da hemşire ve teknisyenler $(p=1.0)$ arasında istatistiksel olarak anlamlı fark saptanmadı. Acil travma ekip liderleri açııından bakıı ığında, bu uygulamanın kullanımı ile iletişim için zaman kaybı ve ekip liderinin iş yükü azaltılabilmiştir.

TARTIŞMA: Akıllı telefonlar için anlık mesajlaşma uygulamaları, tıbbi bilgi transferi ve hastanelerde acil müdahale ekibi üyelerinin koordinasyonu için etkin, kullanımı kolay ve zaman tasarrufu sağlayan bir iletişim aracı olabilir.

Anahtar sözcükler: Ateşli silah yaralanmaları; medikal iletişim; travma.

Ulus Travma Acil Cerrahi Derg 2017;23(3):207-21। doi: 10.5505/tjtes.2016.37897 